\title{
Seasonality and the Relationships Between Reproductive and Leaf Phenophases In Myrtaceae Using Field and Herbarium Data
}

\author{
Jonathan Tejeda Orellana ${ }^{1}$ \\ Jociene Oliveira Vitória Nascimento ${ }^{1}$ \\ Jorge Grilo ${ }^{1}$ \\ Sâmia Paula Santos Neves ${ }^{1}$ \\ Lia D’Afonsêca Pedreira de Miranda ${ }^{1}$ (1) \\ Ligia Silveira Funch ${ }^{1}$ (])
}

\begin{abstract}
Phenological studies are considerably complemented through field data and herbarium collection databases. We examined the seasonality and relationships between leafing and reproductive phenophases using field observations and herbarium data of Campomanesia eugenioides var. desertorum, Eugenia punicifolia, and Psidium schenckianum, all native species of Myrtaceae. Field observations were performed in a caatinga remnant in Bahia State, Brazil; HUEFS herbarium collections were examined. In general, all species showed seasonal reproductive phases and aseasonal leaf phases, and Spearman correlations were observed between those phases. Field observations and herbarium collections were similar and complementary, providing clues about seasonality and the relationship between leaf and reproductive phases of Myrtaceae species.
\end{abstract}

Keywords: phenology, tropical plants, Campomanesia eugenioides, Eugenia punicifolia, Psidium schenckianum.

Myrtaceae comprises approximately 5000 species distributed in tropical and subtropical regions, with South America being one of its main centers of diversity (Wilson, 2011). Twenty-three genera and 1027 species have been recorded for Brazil, with Eugenia P. Micheli ex L., Myrcia DC. ex Guill., and Psidium L. being the most abundant genera (Flora do Brasil 2020 under construction). Species richness occurs mainly in the Atlantic Forest and the caatinga domain (Sobral et al., 2013). The economic importance is recognized in terms of the production of wood, cellulose, substances with medicinal properties, and food resources (Souza \& Lorenzi, 2012).

Tropical phenological studies have gathered considerable qualitative and quantitative data concerning focal trees with great utility for understanding forest ecosystem functioning (Mendoza et al., 2018; Pires et al., 2016). Phenological seasonality is the association between the occurrence of a certain phenophase and a season (Newstron et al., 1994). As Myrtaceae is an important arboreal component of tropical forests, the phenology of the family has been the subject of several studies and evidenced flowering and fruiting seasonality
(Staggemeier et al., 2010; 2015; 2016). Most species have been treated as evergreen, although leaf phenology and relationships between leaf and reproductive phenophases (Fonseca, 2008; Moraes et al., 2017) have received little attention.

Herbarium collections represent potential sources of phenological information on tropical tree species and have long been utilized to supplement phenological field studies (e.g. Borchert, 1996; Mori et Prance, 1986), to understand patterns of plant phenology (e.g., Souza et Funch, 2017), and can contribute to conservation efforts (e.g., Banaszak et al., 2020) - but have only been used to exame reproductive phenophases, never leaf phases. We sought to examine the seasonality of native species of Myrtaceae, and the relationships between their leaf and reproductive phenophases, using field and herbarium data.

The focal species were shrubs or small trees 1.5-8 m tall: Campomanesia eugenioides var. desertorum (DC.) Landrum, ("cambuí", "araçaî", and "araçarico"), which produces edible fruits and occurs in restinga, caatinga, and cerrado vegetation formations from Santa Catarina to Pernambuco (Oliveira et al., 2012);

${ }^{1}$ Universidade Estadual de Feira de Santana, Feira de Santana, BA, Brasil. 
Eugenia punicifolia (Kunth) DC. ("pitanga-do-campo"), widely distributed in cerrado, caatinga, campo rupestre, and forests in Brazil, Paraguay, and Venezuela (Sobral, 1987); and Psidium schenckianum Kiaersk. ("araçá"), common in caatinga and dry forest phytophysiognomies (Sobral, 2013; Landrum, 2017). Their populations were in caatinga remnants on the campus of the Bahia State University at Feira de Santana - UEFS, Brazil, inserted within a dry to sub-humid region with a mean annual temperature of $23.5^{\circ} \mathrm{C}$ and mean annual rainfall of $802 \mathrm{~mm}$ (Source: UEFS weather station). Phenological observations were performed monthly from September/2011 to September/ 2012 on marked individuals of $C$. eugenioides var. desertorum $(\mathrm{n}=44)$, E. punicifolia $(\mathrm{n}=59)$, and $P$. schenckianum $(\mathrm{n}=50)$. The phenophases of young leaves (including leaf budding), mature leaves, flowering (budding and flowering), and fruiting (immature and ripe fruits) were monitored. Herbarium data were obtained through reviews of 458 vouchers deposited at the UEFS (HUEFS) [C. eugenioides var. desertorum $(\mathrm{n}=87$ specimens), E. punicifolia $(\mathrm{n}=278)$, and $P$. schenckianum $(\mathrm{n}=93)]$. The selection of herbarium specimens considered: (1) the professionals responsible for their identification; (2) the presence of both young and mature leaves (considering leaf expansion and texture), flowers, and fruits; (3) collection location and date. We examined seasonality for both field and herbarium phenological data using circular statistics using Oriana 4.02 software (Kovach Computing Services, http://www.kovcomp.co.uk). The frequency of each phenophase was calculated based on the total number of individuals/ vouchers showing the phases per month. Months were converted into angles at $30^{\circ}$ intervals. The mean angles and $r$ vector lengths were calculated. Angle significance was tested using the Rayleigh test ( $\mathrm{z}$ ) for circular distributions (Zar, 2010). The phenological events with significant mean angles $(p<0.05)$ were transformed into mean dates. Phenophases whose vector lengths $(r)$ were $>0.5$, and which the Rayleigh test indicated as significant, were considered seasonal (Morellato et al., 2010). We examined correlations between leaf and reproductive phenophases for both field and herbarium phenological data using Spearman's correlation coefficients (rs) calculated using R software 1.2.1335 (R core Team 2019). The normality of the phenological data was tested based on Shapiro \& Wilk (Zar 2010).
All three species demonstrated seasonality in their reproductive phenophases in both the field and in herbarium collections, except $E$. punicifolia, which did not appear seasonal in the herbarium data; leaf phenophases were generally not seasonal, except for young leaves in P. schenckianum (field) and young and mature leaves in C. eugenioides var. desertorum (herbarium) (Table 1; Figure 1). The greatest flowering activities (budding and flowering) occurred simultaneously with the production of young leaves (including leaf budding) in C. eugenioides var. desertorum, E. punicifolia, and P. schenckianum in both field and herbarium data (Figure 1). There were correlations between young leaves and flowering and fruiting phenophases, principally in C. eugenioides var. desertorum and $P$. schenckianum in terms of both field and herbarium data (Table 2).

The results of the analysis of the collections housed at the HUEFS herbaria indicated a tendency towards seasonality of both the flowering and fruiting periods among the Myrtaceae species, although this behavior was not found to be as pronounced for fruiting as for flowering. The results of our field studies likewise indicated that flowering was associated with specific periods of the year (between November to January), corroborating earlier phenological studies (Fonseca, 2008; Staggemeier et al., 2010; 2015). The herbarium data from the present study indicated that fruiting is less seasonal than flowering, which could be explained by differences in fruit size and the length of the period required for maturation (Smith-Ramirez et al., 1998; Staggemeier et al., 2010; 2015; 2016).

The relationship between phases was evidenced, mainly in species showing more restricted distributions such as $C$. eugenioides var. desertorum and P. schenckianum - both more frequent in caatinga environments (Oliveira et al., 2012; Landrum, 2017), where seasonal water restrictions are strong drivers of plant ecological strategies (Neves et al., 2017). The field data of E. punicifolia reveals the initial development of young leaves, with flower bud development occurring slightly later (Moraes et al., 2017).

Our field observations of a small number of trees in a limited area, added to herbarium collections from a species' entire range, were similar and complementary, providing clues about seasonality and the relationships between leaf and reproductive phases of the Myrtaceae studied species. 
Table 1. Circular analysis of phenological events of Campomanesia eugenioides var. desertorum (DC.) Landrum, Eugenia punicifolia (Kunth) DC. and Psidium schenckianum Kiaersk. from field and herbarium data. Observations were performed in caatinga remnants at the campus of Universidade Estadual de Feira de Santana (UEFS), in Feira de Santana, Bahia, Brazil. Herbarium data were obtained from the collection of the HUEFS.

\begin{tabular}{|c|c|c|c|c|c|c|c|c|}
\hline & \multicolumn{8}{|c|}{ Campomanesia eugenioides var desertorium } \\
\hline & \multicolumn{2}{|c|}{ Flowering } & \multicolumn{2}{|c|}{ Fruiting } & \multicolumn{2}{|c|}{ Young leaf } & \multicolumn{2}{|c|}{ Mature leaf } \\
\hline & Field & Herbarium & Field & Herbarium & Field & Herbarium & Field & Herbarium \\
\hline Mean vector $(\mathrm{u})$ & $315.615^{\circ}$ & $342.00^{\circ}$ & $15.9^{\circ}$ & $45.90^{\circ}$ & $265.98^{\circ}$ & $18.75^{\circ}$ & $106.58^{\circ}$ & $24.93^{\circ}$ \\
\hline Length of mean vector $r$ & 1 & 0.66 & 0.61 & 0.53 & 0.08 & 0.56 & 0.05 & 0.50 \\
\hline Rayleigh Test (z) & 16.01 & 1453.82 & 22.49 & 1716.96 & 4.72 & 1845.55 & 2.20 & 2138.36 \\
\hline Rayleigh Test (p) & $<1.11 \mathrm{E}-07$ & $<1 \mathrm{E}-12$ & $<1.70 \mathrm{E}-10$ & $<1 \mathrm{E}-12$ & 0.009 & $<1 \mathrm{E}-12$ & 0.11 & $<1 \mathrm{E}-12$ \\
\hline \multirow[t]{4}{*}{ Grand Mean group } & October & December & January & February & September & January & April & January \\
\hline & \multicolumn{8}{|c|}{ Eugenia punicifolia (Kunth) DC } \\
\hline & \multicolumn{2}{|c|}{ Flowering } & \multicolumn{2}{|c|}{ Fruiting } & \multicolumn{2}{|c|}{ Young leaf } & \multicolumn{2}{|c|}{ Mature leaf } \\
\hline & Field & Herbarium & Field & Herbarium & Field & Herbarium & Field & Herbarium \\
\hline Mean vector $(\mathrm{u})$ & $353.10^{\circ}$ & $99.63^{\circ}$ & $52.88^{\circ}$ & $146.24^{\circ}$ & $246.08^{\circ}$ & $127.56^{\circ}$ & $261.83^{\circ}$ & $127.06^{\circ}$ \\
\hline Length of mean vector $r$ & 0.52 & 0.36 & 0.68 & 0.25 & 0.40 & 0.25 & 0.00 & 0.27 \\
\hline Rayleigh Test $(\mathrm{z})$ & 63.01 & 1534.56 & 154.68 & 1118.30 & 71.40 & 1073.07 & 0.00 & 2003.10 \\
\hline Rayleigh Test (p) & $<1 \mathrm{E}-12$ & $<1 \mathrm{E}-12$ & $<1 \mathrm{E}-12$ & $<1 \mathrm{E}-12$ & $<1 \mathrm{E}-12$ & $<1 \mathrm{E}-12$ & 0.00 & $<1 \mathrm{E}-12$ \\
\hline \multirow[t]{4}{*}{ Grand Mean group } & December & April & February & May & September & May & September & May \\
\hline & \multicolumn{8}{|c|}{ Psidium schenkianum } \\
\hline & \multicolumn{2}{|c|}{ Flowering } & \multicolumn{2}{|c|}{ Fruiting } & \multicolumn{2}{|c|}{ Young leaf } & \multicolumn{2}{|c|}{ Mature leaf } \\
\hline & Field & Herbarium & Field & Herbarium & Field & Herbarium & Field & Herbarium \\
\hline Mean vector $(\mathrm{u})$ & $282.16^{\circ}$ & $340.45^{\circ}$ & $67.89^{\circ}$ & $83.85^{\circ}$ & $242.77^{\circ}$ & $357.18^{\circ}$ & $123.69^{\circ}$ & $64.48^{\circ}$ \\
\hline Length of mean vector $r$ & 0.63 & 0.49 & 0.45 & 0.49 & 0.54 & 0.29 & 0.01 & 0.26 \\
\hline Rayleigh Test (z) & 92.34 & 791.60 & 129.14 & 1460.62 & 133.11 & 381.4 & 0.09 & 593.49 \\
\hline Rayleigh Test (p) & $<1 \mathrm{E}-12$ & $<1 \mathrm{E}-12$ & $<1 \mathrm{E}-12$ & $<1 \mathrm{E}-12$ & $<1 \mathrm{E}-12$ & $<1 \mathrm{E}-12$ & 0.91 & $<1 \mathrm{E}-12$ \\
\hline Grand Mean group & October & December & May & March & September & December & May & March \\
\hline
\end{tabular}

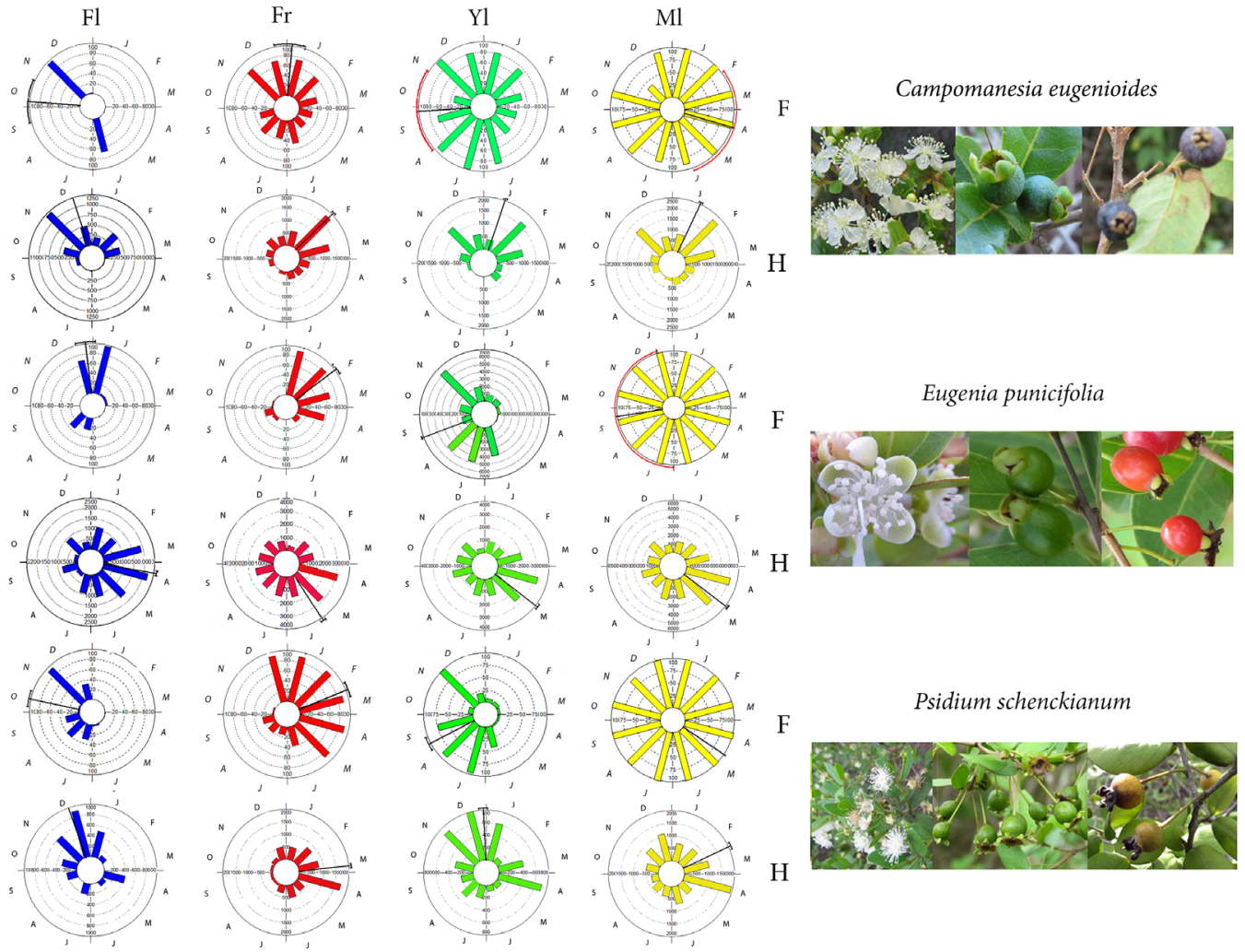

Figure 1. Circular histograms of the individual frequencies of flowering (Fl), fruiting ( $\mathrm{Fr}$ ), young leaves (Yl), and mature leaves ( $\mathrm{Ml})$ of Campomanesia eugenioides var. desertorum (DC.) Landrum, Eugenia punicifolia (Kunth) DC., and Psidium schenckianum Kiaersk. based on field observations $(\mathrm{F})$ and herbarium $(\mathrm{H})$ data. To the right, images of the corresponding species showing flowers, fruits, and leaves. For details of the analyses, see Table 1. 
Table 2. Spearman correlation between leaves and reproductive phenophases of Campomanesia eugenioides var. desertorum (DC.) Landrum, Eugenia punicifolia (Kunth) DC. and Psidium schenckianum Kiaersk. based on field and herbarium data.

\begin{tabular}{|c|c|c|c|c|c|c|c|c|}
\hline \multirow{2}{*}{ Species } & \multicolumn{2}{|c|}{ YL / FL } & \multicolumn{2}{|c|}{ YL / FR } & \multicolumn{2}{|c|}{ ML / FL } & \multicolumn{2}{|c|}{ ML / FR } \\
\hline & Field & Herb & Field & Herb & Field & Herb & Field & Herb \\
\hline Campamonesia eugenioides & 0.5599 & 0.5874 & 0.7133 & & 0.7055 & & & 0.6633 \\
\hline Eugenia punicifolia & & & -0.6831 & & & & & \\
\hline Psidium schenkianum & 0.8984 & 0.6244 & -0.6733 & 0.7018 & 0.6770 & & 0.5417 & \\
\hline
\end{tabular}

\section{ACKNOWLEDGEMENTS}

The authors would like to thank the Conselho Nacional de Desenvolvimento Científico e Tecnológico (CNPq 480508/2008-09) and the Fundação de Amparo à Pesquisa do Estado da Bahia (FAPESB 5303/2009) for financing this research project, and the Universidade Estadual de Feira de Santana for the use of their infrastructure and assistance with the fieldwork.

\section{SUBMISSION STATUS}

Received: 8 May. 2020

Accepted: 9 September. 2020

Associate editor: João Vicente Latorraca

\section{CORRESPONDENCE TO}

\section{Ligia Silveira Funch}

Universidade Estadual de Feira de Santana, Feira de Santana, Rua Miami, 800, CEP 44036-900, Feira de Santana, BA, Brasil. e-mail: ligiafunch@yahoo.com

\section{REFERENCES}

Banaszak C, Grinath JB, Herlihy CR. Chilling consequences: Herbarium records reveal earlier reproductive phenology of winter annual gladecress in a wetter, cooler climate. Plants, People, Planet $2020 ; 2: 340-352$.

Borchert R. Phenology and Flowering Periodicity of Neotropical Dry Forest Species: Evidence from Herbarium Collections. Journal of Tropical Ecology 1996; 12(1):65-80.

Flora do Brasil, under construction. Jardim Botânico do Rio de Janeiro [cited 2020 march, 18]. Available at: http://floradobrasil. jbrj.gov.br/>.

Fonseca RBS. Fenologia de espécies de Myrtaceae: padrões, causas e consequências. [tese] Feira de Santana: Programa de Pós- Graduação em Botânica, Universidade Estadual de Feira de Santana; 2008

Landrum LR. The genus Psidium (Myrtaceae) in the state of Bahia, Brazil. Herbarium, Natural History Collections, School of Life Sciences, Arizona State University 2017.

Mendoza I, Condit RS, Wright SJ, Caubère A, Chátelet P, Hardy I, Forget P. Inter-annual variability of fruit timing and quantity at
Nouragues (French Guiana): insights from hierarchical Bayesian analyses. Biotropica 2018; 50(3): 431-441.

Moraes ACDS, Vitoria AP, Rossatto DR, Miranda, LAP, Funch LS. Leaf phenology and morphofunctional variation in Myrcia amazonica DC. (Myrtaceae) in gallery forest and "campo rupestre" vegetation in the Chapada Diamantina, Brazil. Brazilian Journal of Botany 2017; 40(2): 439-450.

Morellato LPC, Alberti LF, Hudson IL. Applications of circular statistics in plant phenology: a case studies approach. In: Hudson IL, Keatley M, editors, Phenological research: methods for environmental and climate change analysis. Springer; 2010.

Mori SA, Prance GT. Phenology. In: Mori SA, editor, The Lecythidaceae of a lowland neotropical forest: La Fum Ce mountain, French Guiana. Memoirs of the New York Botanical Garden 1987; 40:124-135.

Newstrom LE, Frankie GW, Bake RHG. A new classification for plant phenology based on flowering patterns in lowland tropical rains forest at La Selva, Costa Rica. Biotropica 1994; 26:141-159.

Neves SPS, Miranda LAP, Rossatto DR, Funch LS. The roles of rainfall, soil properties, and species traits in flowering phenology along a savanna-seasonally dry tropical forest gradient. Revista Brasileira de Botânica (Impresso) 2017; 40(3): 665-679.

Oliveira MIUD, Funch LS, Landrum LR. Flora of Bahia: Campomanesia (Myrtaceae). Sitientibus série Ciências Biológicas 2012; 12(1): 91-107.

Pires HCG, Rosa LS, Cabral BS, Silva VM, Nogueira GA, Ferreira PRN. Padrão fenológico de Attalea maripa (Aubl.) Mart. em áreas de pastagens na Amazônia Oriental. Floresta e Ambiente 2016; 23(2): 170-179.

R Core Team. 2014. R: a language and environment for statistical computing. Vienna, R Foundation for Statistical Computing.

Smith-Ramírez C, Armesto JJ, Figueroa J. Flowering, fruiting and seed germination in chilean rain forest Myrtaceae: ecological and phylogenetic constraints. Plant Ecology 1998; 136(2): 119-131.

Sobral M. La Sinonimia de Eugenia punicifolia (Kunth) DC. (Myrtaceae). Candollea 1987; 42: 807-811.

Sobral M, Proença C, Souza M, Mazine F, Lucas E. Myrtaceae. In: Lista de Espécies da Flora do Brasil. Rio de Janeiro: Jardim Botânico do Rio de Janeiro 2013; [consulted on March 18, 2020]. Available at: http://floradobrasil.jbrj.gov.br/jabot/floradobrasil/FB10307 
Souza IM, Funch LS. Synchronization of leafing and reproductive phenological events in Hymenaea L. species (Leguminosae, Caesalpinioideae): the role of photoperiod as the trigger. Brazilian Journal of Botany, 2017; 40(1): 125-136.

Souza VC, Lorenzi H. Botânica Sistemática: guia ilustrado para identificação das famílias de fanerógamas nativas e exóticas no Brasil, baseado em APG III 2012.

Staggemeier VG, Diniz-Filho JAF, Morellato LPC. The shared influence of phylogeny and ecology on the reproductive patterns of Myrteae (Myrtaceae). Journal of Ecology 2010; 98(6): 1409-1421.
Staggemeier VG, Diniz-Filho JAF, Zipparro VB, Gressler E, Castro ERD, Mazine F. Clade-specific responses regulate phenological patterns in Neotropical Myrtaceae. Perspectives in Plant Ecology, Evolution and Systematics 2015; 17(6): 476-490.

Staggemeier VG, Cazetta E, Morellato LPC. Hyperdominance in fruit production in the Brazilian Atlantic rain forest: the functional role of plants in sustaining frugivores. Biotropica, 2016; 0(0): 1-12.

Wilson PG. Myrtaceae. In: Kubitzki, K, editor. Flowering plants. Eudicots: The families and genera of vascular plants. Springer 2011; 10, 212-271.

Zar JH. Biostatistical analysis. New Jersey: Prentice-Hall; 2010. 